\title{
Biology of Bombyx mori L. at Talwandi Sabo, Punjab-Short Communication
}

\author{
Harpreet Singh ${ }^{1 *}$, Anita Singh ${ }^{2}$, Jora Singh Brar ${ }^{3}$ \\ ${ }^{1}$ Student, Department of Entomology, UCoA, Guru Kashi University, Talwandi Sabo (BTI), Punjab, India \\ ${ }^{2}$ Former Assistant Professor, Department of Entomology, UCoA, Guru Kashi University, Talwandi Sabo (BTI), Punjab, India \\ ${ }^{3} \mathrm{HOD}$, Department of Entomology, UCoA, Guru Kashi University, Talwandi Sabo (BTI), Punjab, India
}

*Address for Correspondence: Mr. Harpreet Singh, Student, Department of Entomology, UCoA, Guru Kashi University, Talwandi Sabo (BTI), Punjab, India

E-mail: dr.dandiwal@gmail.com

Received: 17 Jul 2018/ Revised: 26 Nov 2018/ Accepted: 23 Feb 2019

\begin{abstract}
The biology of the Mulberry silkworm was studied under laboratory conditions from January 2018 to April 2018 at Department of Entomology, Guru Kashi University, Talwandi Sabo. The results revealed that the female an average oviposition period was of $20.2 \pm 2.38$ hour whereas; single female laid on an average $107.8 \pm 11.04$ eggs. The average total larval period was of $23.7 \pm 0.95$ days. The average pupal period was of $10.36 \pm 1.25$ days. The average adult emergence period was of $54.92 \pm 5.62$ days. The longevity of the female and male was also recorded. The results revealed that female lived for5.64 \pm 0.48 days and male survived for $4.68 \pm 0.47$ days. In future, this research will be helpful for starting the sericulture in non-traditional places.
\end{abstract}

Key-words: Longevity, Monophagous insect, Mulberry, Oviposition, Silk moth

\section{INTRODUCTION}

In India, silk production percentage was $15 \%$ of total world production ${ }^{[1]}$. Generally, four kinds of silkworm are used for silk production. Those are Mulberry, Eri, Tasar and Muga. But in these Mulberry silkworms are producing $89.45 \%$ of silk ${ }^{[1]}$. Production of silk is major agro-based rural industry ${ }^{[2]}$. This Bombyx mori L. is a monophagous insect that feeds exclusively on mulberry leaves. In India, five states i.e. Karnataka, Jammu \& Kashmir, Tamilnadu, Andra Pradesh, and West Bengal are the traditional state for silk production ${ }^{[1,2]}$. But very less work was done in the field of sericulture at Punjab. Therefore present investigation was conducted on, to study the biology of $B$. mori under laboratory condition using mulberry leaves at Talwandi Sabo.

\section{How to cite this article}

Singh H, Singh A, Brar JS. Biology of Bombyx mori L. at Talwandi Sabo, Punjab-Short Communication. SSR Inst. Int. J. Life Sci., 2019; 5(2): 2230-2234.

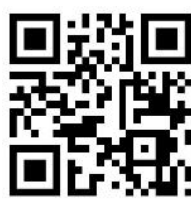

\section{MATERIALS AND METHODS}

Silkworm immature (just after emergence) was collected from Regional Sericulture Research Station, Central Silk Board, Government of India, Sujanpur during Dec 2017. The collected larva was brought to the Entomology Laboratory at Guru Kashi University, Talwandi Sabo. The leaves of mulberry were collected from the University campus and surrounding area at Talwandi Sabo. These collected leaves were cleaned with distilled water. After cleaning, leaves were chopped into small pieces and given to the newly emerged larvae as food the mulberry leaf food was daily provided to these larvae. The routine hygiene was also maintained at the laboratory. Further, oviposition period, each larvae duration, and total larval duration were recorded. The last larval stages of silkworm were kept in separate containers heaving dry woods for pupation. The total days for pupa formation were also recorded. The newly formed pupae were kept in insect cages for adult emergence. Further the total adult emergence period was recorded. The newly emerged male and female silk moths were separated and kept in separate containers for mating. After mating, the female silk moths started laying eggs. Further, the total number of eggs per female was recorded. 
The male and female silk moth longevity was also recorded. The entire recorded data was transferred on worksheet Microsoft excel 2013 for statistical analysis.

\section{RESULTS}

The result revealed that the single silk moth female laid on an average $107.8 \pm 11.04$ eggs. Total $20.2 \pm 2.38$ hours were the average oviposition period of mulberry silk moth (Table 1). The average larval duration for first, second, third, fourth, and fifth larval instars were recorded as $3.56 \pm 0.51,3.60 \pm 0.5,4.48 \pm 0.51,5.56 \pm 0.51$, and $6.48 \pm 0.51$ days respectively. Total $23.68 \pm 0.95$ days were recorded as average total larval period (Table 2).
Fully grown silk moth fifth in stars larva stopped feeding, became restless, sluggish and gradually raised their head and start spinning for forming cocoon. The average prepupal period was of $2.6 \pm 0.5$ days. The average pupal period of mulberry silk moth was of $10.36 \pm 1.25$ days (Table 2). Cocoon or pupa was oval shaped and full white in colored.

The adults were emerged after forming holes in the cocoons. The average adult emergence period was of $54.92 \pm 5.62$ days. The longevity results revealed that female lived for $5.64 \pm 0.48$ days and male survived for $4.68 \pm 0.47$ days (Table 1 ).

Table 1: Total Adult emergence period, Adult longevity, Fecundity and Oviposition period of B. mori

\begin{tabular}{|c|c|c|c|c|c|}
\hline \multirow{2}{*}{$\begin{array}{c}\text { No. of } \\
\text { Observation }\end{array}$} & \multirow{2}{*}{$\begin{array}{l}\text { Total Adult Emergence } \\
\text { Period (days) }\end{array}$} & \multicolumn{2}{|c|}{ Adult Longevity (Days) } & \multirow{2}{*}{$\begin{array}{l}\text { Fecundity } \\
\text { (No. of Eggs) }\end{array}$} & \multirow{2}{*}{$\begin{array}{l}\text { Oviposition } \\
\text { Period (hrs) }\end{array}$} \\
\hline & & Male & Female & & \\
\hline 1 & 62 & 4 & 5 & 121 & 21 \\
\hline 2 & 63 & 5 & 6 & 97 & 17 \\
\hline 3 & 47 & 5 & 5 & 104 & 18 \\
\hline 4 & 49 & 5 & 5 & 114 & 24 \\
\hline 5 & 50 & 5 & 6 & 101 & 23 \\
\hline 6 & 52 & 5 & 5 & 117 & 17 \\
\hline 7 & 63 & 4 & 6 & 120 & 22 \\
\hline 8 & 63 & 4 & 5 & 111 & 20 \\
\hline 9 & 51 & 5 & 5 & 94 & 17 \\
\hline 10 & 52 & 5 & 6 & 119 & 19 \\
\hline 11 & 61 & 4 & 5 & 106 & 23 \\
\hline 12 & 58 & 4 & 5 & 120 & 21 \\
\hline 13 & 53 & 5 & 6 & 110 & 18 \\
\hline 14 & 49 & 5 & 6 & 96 & 21 \\
\hline 15 & 62 & 4 & 6 & 88 & 17 \\
\hline
\end{tabular}


16

17

18

19

20

21

22

23

24

25

Mean \pm SD

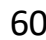

52

51

49

61

54

50

48

60

53

$54.92 \pm 5.62$
114

89

93

122

109

114

21

91

17

116

19

115

19

6

114

23

$4.68 \pm 0.47$

$5.64 \pm 0.48$

$107.8 \pm 11.04$

$20.2 \pm 2.38$

Table 2: Duration of larval instars, Total larval period, Prepupal period and Pupal period in B. mori

\begin{tabular}{|c|c|c|c|c|c|c|c|c|}
\hline \multirow{2}{*}{$\begin{array}{c}\text { No. of } \\
\text { Observation }\end{array}$} & \multicolumn{5}{|c|}{ Duration of larval instars of B. mori (days) } & \multirow{2}{*}{$\begin{array}{l}\text { Total } \\
\text { Larval } \\
\text { Period } \\
\text { (days) }\end{array}$} & \multirow{2}{*}{$\begin{array}{c}\text { Pre } \\
\text { pupal } \\
\text { Period } \\
\text { (days) }\end{array}$} & \multirow{2}{*}{$\begin{array}{l}\text { Pupal } \\
\text { Period } \\
\text { (days) }\end{array}$} \\
\hline & $1^{\text {st }}$ & $2^{\text {nd }}$ & $3^{\text {rd }}$ & $4^{\text {th }}$ & $5^{\text {th }}$ & & & \\
\hline 1 & 3 & 4 & 5 & 5 & 7 & 24 & 3 & 9 \\
\hline 2 & 4 & 4 & 4 & 6 & 7 & 25 & 2 & 9 \\
\hline 3 & 4 & 3 & 4 & 5 & 6 & 22 & 3 & 10 \\
\hline 4 & 3 & 3 & 5 & 5 & 7 & 23 & 3 & 9 \\
\hline 5 & 3 & 4 & 4 & 6 & 6 & 23 & 3 & 9 \\
\hline 6 & 3 & 4 & 4 & 5 & 7 & 23 & 3 & 10 \\
\hline 7 & 4 & 3 & 5 & 6 & 7 & 25 & 2 & 12 \\
\hline 8 & 4 & 4 & 5 & 6 & 6 & 25 & 2 & 10 \\
\hline 9 & 4 & 4 & 4 & 6 & 6 & 24 & 3 & 11 \\
\hline 10 & 3 & 4 & 5 & 5 & 6 & 23 & 3 & 9 \\
\hline 11 & 4 & 3 & 5 & 6 & 7 & 25 & 2 & 12 \\
\hline
\end{tabular}




\begin{tabular}{ccccccccc}
\hline 12 & 4 & 4 & 4 & 6 & 6 & 24 & 3 & 10 \\
13 & 3 & 3 & 5 & 5 & 7 & 23 & 2 & 9 \\
14 & 4 & 3 & 4 & 5 & 6 & 22 & 2 & 9 \\
15 & 4 & 4 & 5 & 6 & 6 & 25 & 2 & 11 \\
16 & 3 & 3 & 5 & 6 & 6 & 23 & 3 & 12 \\
17 & 3 & 4 & 4 & 6 & 6 & 23 & 3 & 10 \\
18 & 3 & 4 & 4 & 5 & 7 & 23 & 3 & 9 \\
19 & 4 & 3 & 5 & 5 & 7 & 24 & 2 & 12 \\
20 & 4 & 3 & 4 & 6 & 6 & 23 & 3 & 11 \\
21 & 3 & 4 & 5 & 6 & 6 & 24 & 3 & 12 \\
22 & 4 & 3 & 4 & 6 & 7 & 24 & 2 & 9 \\
23 & 4 & 4 & 4 & 5 & 6 & 23 & 3 & 12 \\
$\mathbf{2 4}$ & 3 & 4 & 5 & 6 & 7 & 25 & 3 & 12 \\
Mean & $3.56 \pm 0.51$ & $3.6 \pm 0.50$ & $4.48 \pm 0.51$ & $5.56 \pm 0.51$ & $6.48 \pm 0.51$ & $23.68 \pm 0.95$ & $2.6 \pm 0.50$ & $10.36 \pm 1.25$ \\
\hline
\end{tabular}

\section{DISCUSSION}

Observations in this study showed that single female laid on an average $107.8 \pm 11.04$ eggs, contrary to Patel et al. ${ }^{[3]}$, who reported $269 \pm 30.23$ eggs per female silk moth as average fecundity rate. The average oviposition period in the present study was of $20.2 \pm 2.38$ hours, whereas Silayach and Khokhar ${ }^{[4]}$ reported 14.97 hours as an average oviposition period of mulberry silkmoth.

The average total larval period was of $23.68 \pm 0.95$ days. The result obtained by this study confirm with earlier study done by Tiku et al. ${ }^{[2]}$, who also reported the total larva duration of silk moth as of $23.77 \pm 0.744$ days. Meshram ${ }^{[5]}$ worked on B. mori at Chhattisgarh recorded $26.23 \pm 1.18$ days for the total larval duration. Kaleem et al. ${ }^{[6]}$ when worked with new strain of mulberry silk moth revealed that total larval period was of $24.44 \pm 1.51$ days. Whereas, Alvarez ${ }^{[7]}$ recorded total larval period of 33.0 days in mulberry silk moth.

In the present study, the average prepupal period and pupal period was of $2.6 \pm 0.5$ and $10.36 \pm 1.25$ days. This finding had similar to Tiku et al. ${ }^{[2]}$ who recorded 2.29 \pm 0.46 and
$10.20 \pm 0.92$ days for average pre-pupal, and total pupal period, respectively. The longevity results revealed that female lived for $5.64 \pm 0.48$ days and male survived for $4.68 \pm 0.47$ days. Similar kind of study conducted by Doddaswami and Subramanva ${ }^{[8]}$ was also revealed that the female lived longer than male and the average longevity of male and female was of $5.60 \pm 0.70 \& 6.23$ \pm 0.43 days respectively.

\section{CONCLUSIONS}

Mulberry silkworm female laid on an average $107.80 \pm 11.04$ eggs in it life span. The oviposition period was $20.20 \pm 2.38$ days and total larval period was of $23.68 \pm 0.94$ days. Total pupal periods were $10.36 \pm 1.25$ days. The adult emerged from pupa in $54.92 \pm 5.62$ days. The female silk moth lived longer than male silk moth. Therefore, in future these types of studies will motivate farmers to adopt sericulture for their economic development and will be helpful for starting the sericulture in non-traditional places. 


\section{ACKNOWLEDGMENTS}

Authors were sincerely thankful to Regional Sericulture Research Station, Central Silk Board, Government of India, Sujanpur for providing silkworm and Guru Kashi University Dean for providing all laboratory facility.

\section{CONTRIBUTION OF AUTHORS}

Research concept - Dr. Anita Singh, Dr. Jora Singh Brar

Research design- Dr. Anita Singh

Supervision- Dr. Anita Singh

Material- Dr. Jora Singh Brar, Dr. Anita Singh

Data collection-Harpreet Singh

Dataanalysis and interpretation-Harpreet Singh

Literature search-Harpreet Singh

Writing article-Harpreet Singh

Critical review-Dr. Anita Singh

Article editing-Harpreet Singh

Final approval- Dr. Anita Singh

\section{REFERENCES}

[1] Anitha R. Indian silk industry in the global scenario. Excel Int. J. Multidiscip. Manag. Stud., 2011; 1(3): 100-10.

[2] Tiku SG, Siddhaparu, Surari PM. Biology of Mulberry silkworm, Bombyx mori L. on mulberry, Morus alba L. J. Entomol. Zool. Stud., 2018; 6(4): 276-80.
[3] Patel SR, Pandya HV, Patel SD, Naik MM. Biology of Bombyx mori L. (Lepidoptera: Bombycidae). Int. J. Plant Prot., 2013; 6(2): 382-89.

[4] Silayach US, Khokhar KS. The biology of silkworm Bombyx mori L. on various cultivars of mulberry. Rev. Agric. Entomol., 1995; 85(2): 1256.

[5] Meshram YK. Mulberry silkworm (Bombyx mori L.) a study on its biometric variation and food utilization during the two successive generation in Chhattisgarh state. M.Sc. (Agri.) Thesis, submitted to Indira Gandhi Agricultural University, Raipur, 2002.

[6] Kaleem S, Mahmood I, Ahmad M, Bukhsh MA, Wasaya $A$, et al. Studies on biology of a new strain (K2) of silkworm (Bombyx mori L.) under different sets of temperature and humidity. J. Anim. Plant Sci., 2011; 21(3): 556-60.

[7] Alvarez RJA. Biology of silkworm Bombyx mori L. (Lepidoptera: Bombycidae). Rev. Agric. Entomol., 1993; 83(6): 5032.

[8] Doddaswami MS, Subramanva G. Studies on the adults life span of multivoltine and bivoltine races of the silkworm, Bombyx mori L. Indian J. Seric., 2007; 46(2): 106-08. 